\title{
Testing the Neocon Agenda: Democracy in Resource-Rich Societies
}

Paul Collier and Anke Hoeffler,

Department of Economics, University of Oxford

November, 2007

\begin{abstract}
:
Resource-rich countries have tended to be autocratic and also have tended to use their resource wealth badly. The neoconservative agenda of promoting democratization in resource-rich countries thus offers the hopeful prospect of a better use of their economic opportunities. This paper examines whether the effect of democracy on economic performance is distinctive in resource-rich societies. We show that a priori the sign of the effect is ambiguous: resource rents could either enhance or undermine the economic consequences of democracy. We therefore investigate the issue empirically. We first build a new data set on country-specific resource rents, annually for the period 1970-2001. Using a global panel data set we find that in developing countries the combination of high natural resource rents and open democratic systems has been growth-reducing. Checks and balances offset this adverse effect. Thus, resource-rich economies need a distinctive form of democracy with particularly strong checks and balances. Unfortunately this is rare: checks and balances are public goods and so are liable to be undersupplied in new democracies. Over time they are eroded by resource rents.
\end{abstract}

This document is an output from a project funded by the UK Department for International Development (DFID) for the benefit of developing countries. The views expressed are not necessarily those of DFID.

JEL Classification: O11, O40, Q38

Keywords: political economy, natural resources, growth 


\section{Introduction}

Many resource-rich countries have suffered from the 'resource curse': the failure to harness commodity revenues for sustained growth. In this paper we investigate analytically and empirically whether this curse is ameliorated by democracy. The question is at the intersection of two large and active literatures, one accounting for the resource curse and the other investigating the economic consequences of democracy. On the intersection, however, there is to date very little. Yet the intersection is of considerable practical concern. The recent rise in commodity prices has generated revenue booms in commodity exporters that were last experienced in the 1970s. The widespread failure to harness those booms for sustained growth is the empirical basis for the resource curse: hence, whether the present booms will repeat history is of first order importance for a large group of low-income societies. Between the two resource booms one striking institutional change has occurred: resource-rich countries are now on average more democratic. ${ }^{\mathrm{i}}$ The importance of institutions and the scope for changing them are now central controversies in development economics. Thus, our investigation of the economic consequences of democratization in resourcerich countries nests within this larger debate.

The 'neocon agenda' of the United States, combined with two other influences, has increased the prevalence of resource-rich democracies. The agenda diagnosed the perceived ills of the Middle East as being due to its lack of democracy. Thus, Selden (2004) defines the neocon agenda as using:

'American power to reshape the global environment in the name of a set of liberal democratic ideals. It is their belief that this will make the United States more secure by reducing the seemingly intractable problems of the Middle East, thus getting at some of the root causes of terrorism.' 
Democracy as promoted by the American government partly by hard power, as in Iraq, and partly by soft power, exemplified by the first multi-party Egyptian elections held in 2005. The lack of democracy in the Middle East is itself related to the resource abundance of the region: Ross (2001) shows that resource-rich countries are systematically less democratic. In addition to the neocon agenda the 'third wave' of democratization following the fall of the USSR spread to some resource-rich countries. Additionally, some of the resource discoveries triggered by high prices have been in countries that had already democratized.

The concept of the resource curse was initially triggered by particular graphic instances such as Nigeria. There is now a substantial literature exploring both the evidence for the curse and the mechanisms by which it is generated (for example Sachs and Warner (2005), Auty (2001), Gylfason (2001)). There is overwhelming statistical evidence that countries rich in natural resources experienced lower growth rates since 1960. Although the initial statistical evidence was based on cross-section, it is now supported by time series analysis of panel data (Collier and Goderis, 2007, 2007a). The explanation for the curse has also evolved. The initial explanation was the purely economic process of Dutch disease (Corden and Neary, 1982) whereas more recent explanations have been framed in terms of political economy. Tornell and Lane (1999) proposed a 'voracity effect' whereby the high value of resource rents would induce competing political groups to 'gauge' in the process not merely wasting the rents as in conventional rent-seeking, but actually reducing income. The celebrated work of Acemoglu, Johnson and Robinson (2000) also featured a key adverse role for resource rents: inducing institutions suited to extracting rents rather than to the provision of public goods. They proposed that these types of institutions were both distinctive and highly persistent, generating divergent paths of economic development. The two articles to which our work is most closely related are 
Robinson, Torvik and Verdier (2006) and Mehlum, Moene and Torvik (2006) since they address not only why political processes might be dysfunctional in the context of resource rents, but suggest that this may be remedied through appropriate institutions. Robinson, Torvik and Verdier develop a theory of patronage politics in the context of resource wealth and suggest that this dysfunctional behavior may be restrained by good institutions. Mehlum, Moene and Torvik find some empirical support for the idea that institutions are particularly important in the context of natural resources but do not investigate specifically which institutions are important. Both articles rely upon the Sachs and Warner cross-section data set. The present paper extends these studies both analytically, by proposing a more detailed mechanism of political failure, and empirically by using a panel data set and unbundling the concept of 'institutions'.

While the resource curse literature has thus evolved to the stage where institutional weaknesses are regarded as central to the explanation of the curse, it has not yet specifically related these weaknesses either to whether the polity is autocratic rather than democratic, or to variations in democratic design. Yet, as we have noted, democratization has been the main recent institutional innovation in resource-rich countries and in other contexts its effects on economic performance, including the effects of variations in its design, and the possibility of reverse causality from development to democracy, have been intensively studied (Lipset, 1959, Przeworski and Limongi, 1993), Acemoglu, Johnson, Robinson, and Yared, 2008). Overall, the net effect of democracy on economic development is far from clear-cut. Drazen (2000) concludes from a survey of the literature that there is no clear effect. Acemoglu et al. (2008) suggest that different countries are on different long term trajectories, some of which lead to both development and democracy, whereas others 
lead to development without democracy. They do not find any evidence of a causal link between income and democracy but provide some statistical evidence to show that omitted variables, most likely historical variables, jointy determine the political as well as economic development paths. Barro (1996) finds evidence for a non-linear effect: democracy is beneficial at 'intermediate levels'.

None of this literature considers resource rents. For example, it is entirely omitted in the comprehensive survey of theory and evidence by Feng (2003). Yet this neglect is surprising. One of the few clear results of the literature on the economic effects of democracy has been to highlight the problem posed by the shortening of government horizons introduced by the elections for those public decisions that require a longterm view. For example, Tavares and Warziarg (2001) find that democracies have systematically lower investment than autocracies. High investment is central to economic management in resource-rich countries since extraction depletes assets which must be replaced if increased consumption is to be sustained. While this suggests that democracy might be problematic for resource-rich countries, this adverse effect might be overwhelmed by both the enhanced accountability of public revenues, and by the widening of the power base that democracy facilitates. Or the two opposing effects might broadly neutralize each other, leaving no clear relationship between democracy and economic performance in resource-rich countries.

In Section 2 we consider the mechanisms by which resource rents might either enhance or undermine the contribution of democracy to economic development. We show that a priori either is possible so that the issue can only be resolved empirically. 
In Section 3 we explain a new empirical measure of the rents from natural resource exports, country-by-country, for the period 1970-2001. This is a substantial advance on the empirical proxy that has been standard in the literature, namely the value of primary commodity exports. Evidently, rents differ radically both between different commodities and are not proportional to changes in prices. In Section 4 we use this measure to investigate whether the effect of democracy upon growth is altered by the presence of natural resource rents. We find a large adverse interaction of natural resource rents and electoral competition and a large positive interaction of natural resource rents and checks and balances. We then investigate the routes by which electoral competition and checks and balances might have these effects, and finally show that over the long term checks and balances are endogenous to resource rents. Section 5 concludes.

\section{How might resource rents affect the economic consequences of democracy?}

Potentially democracy might be either more or less advantageous for economic performance if a society has large natural resources. While in the long run democracy is itself liable to be endogenous to resource rents, Smith (2004) plausibly suggests that because institutions usually pre-exist resource discoveries, the effects of the rents are likely to be dependent upon this prior institutional variation. We consider some possible mechanisms that would work in each direction.

Mechanisms that enhance the benefits of democracy 
We suggest two mechanisms by which democracy might lead to a differential improvement in economic performance. Both the economic consequences of autocracy may be made absolutely worse by resource rents, and the economic consequences of democracy may be made absolutely greater.

Autocrats may be particularly predatory in the presence of resource rents. The reasoning is analogous to the famous distinction made by Olson between the roving and the stationary bandit (Olson, 1993). Whereas the roving bandit snatches whatever he can without regard to future consequences for the economy, the stationary bandit must limit predation to a rate that is sustainable. The same argument applies if bandit actions can extend to investments that expand the economy: the roving bandit does not invest, but the stationary bandit invests. Being atypically immobile and highly taxable, natural resource rents reduce the need for an autocrat to invest in the growth of the non-resource private economy. This is indeed close to the explanation of Acemoglu, Johnson and Robinson (2000) as to why autocratic colonial governments were made dysfunctional by the presence of resource rents. An autocrat in resourcescarce economies, whether the British government in colonial Kenya or the communist government of modern China, must develop the private economy if it is to generate significant tax revenues and for this it must provide public goods. In contrast, an autocrat in resource-rich central Africa, whether King Leopold or President Mobutu, can generate revenues without the provision of public goods.

Conversely, democratic governments may be particularly useful in societies with large resource rents. With the sole exception of America, such rents accrue in large part to the government so that resource-rich states have an atypically high level of 
public spending. Suppose, not implausibly, that democracy enhances the accountability of public spending to citizens, preventing it from being captured by powerful minorities. In this case, the pay-off to democracy will be approximately proportional to the share of public spending in GDP and so differentially greater in resource-rich societies. Accountable public spending would be far more beneficial to Angola, where resource revenues alone are a more than half GDP, than to Uganda where public spending in total is only a fifth of GDP.

While we do not develop further these sketches of why democracy might be particularly valuable for resource-rich countries, they do not seem to be readily dismissible as possibilities.

\section{Mechanisms that undermine the benefits of democracy}

We now develop at greater length an exposition of a mechanism that works in the opposite direction. We devote greater length to it partly because it is less obvious than the above mechanisms and also because, based on the results of Section 4, it appears more likely to be correct.

We focus on the functioning of democracy and consider how politicians use public resources subject to restraints. Potentially, these resources can be used either for the provision of public goods or for private patronage. In a well-functioning polity politicians who divert public resources into private patronage suffer both electoral defeat and prosecution. We develop a simple model of these restraints, showing how they may be undermined by natural resource rents. 
In the absence of effective legal restraint political parties face a choice of technologies in how they attract votes. They can adopt the conventional mode of presenting programs to voters which commit to the provision of public goods. Alternatively, they can directly buy votes. In mature democracies vote-buying is not a viable electoral strategy for four reasons. Contracts with voters would be non-enforceable due to secret ballots. Bribe transactions would be liable to criminal prosecution. They would antagonize other voters. Finally, they would be too expensive to be affordable by political parties. However, in the conditions typical of developing countries these four inhibitions may not apply. Bribe contracts may indeed be enforceable because they fit naturally into a prevailing culture of reciprocal exchange: bribes are regarded as gifts which rightly attract obligations (Githongo, 2006). The police and courts may not be sufficiently independent of the political process to prosecute vote-buying. In a prevailing atmosphere of political corruption even electors may find vote-buying acceptable: it is the only benefit they can realistically expect from participation in the democratic process. Finally, political parties may have access to very large sources of finance.

Vote-buying is indeed common in developing countries so political parties evidently regard it as cost-effective. Vicente (2007) conducts a unique randomized analysis of vote-buying in the resource-rich country of Sao Tome, Principe, and finds that it is both widespread and effective in inducing voters to change allegiance. Another widespread strategy that is analytically similar to vote-buying is for the politician to hire a militia which then targets opposition supporters, discouraging them from voting. Since the act of voting is readily observable and identity politics increases the 
observability of allegiance, targeted intimidation may also be a cost-effective use of political finance.

Besley (2006) shows analytically that the weaker is voter information about government performance, and the more that voting is pre-determined by identity, the less traction is available to an honest politician whose intentions are congruent with voters. In these conditions corrupt politicians with dissonant intentions may find votebuying and intimidation highly effective. They can be targeted to the minority of swing voters. Indeed, if many voters follow the instructions of community leaders, by bribing them politicians can purchase votes 'wholesale'. A core argument of Besley is that the motivation of politicians is endogenous to these underlying electoral conditions: where honest politicians with congruent intentions stand little chance of election they will not come forward as candidates. We imagine a political contest in which the underlying conditions completely discourage honest politicians: all the candidates have dissonant intentions and are prepared to be dishonest. Expenditure on bribery and intimidation is cost-effective in election campaigns and will predominate to the extent permitted by political finance. This in turn depends upon how much public revenue can be embezzled from its proper uses. To the extent that public spending cannot be embezzled, even corrupt politicians will find themselves presiding over systems which deliver public goods since these provide some electoral advantage, despite rather than because of their intentions. In effect, public revenues have two different degrees of electoral potency: embezzled money is high-powered because it can be used for bribes, while money that cannot be embezzled can only be used for the less cost-effective strategy of providing public goods. Thus, given our assumptions, public goods are provided not because politicians need to do so in order 
to win votes, but because the checks and balances present in the system prevent them from diverting all revenues to patronage.

Hence, the key issue is the determination of the checks and balances that limit the embezzlement of public resources. Effective checks and balances are themselves a type of public good: to be effective, restraints need to be implemented through a continuous process of public scrutiny. To endogenize this process we introduce a relationship in which citizens are provoked into scrutiny by taxation. This relationship is exemplified in the central demand of the American revolution: "no taxation without representation'. As a proposition in political science it is most closely identified with Tilly (1975), being central to his celebrated explanation of the emergence of government accountability to citizens in Europe. More recently the proposition has been central to the work of Moore (see, for example, Moore, 1998). Brautigam and Knack (2004) provide a clear recent application in their discussion of the problems associated with aid: "when revenues do not depend on the taxes raised from citizens and businesses, there is less incentive for government to be accountable to them' (p.265). Resource rents are a non-tax revenue somewhat analogous to aid. Ross (2004) investigates empirically the link between taxation and representation. Consistent with the Tilly hypothesis he finds that the larger is the share of government expenditure which is financed through taxation the more likely is the government to become representative.

We now develop a simple model that incorporates the above behavioral relationships. Politicians would like to tax heavily in order to generate revenue for patronage, but they are constrained from doing so because high taxation provokes intense scrutiny. 
Patronage expenditures are determined by the product of the tax rate, $t$, taxable income, $Y$, and the proportion of revenue which can be embezzled for patronage, $e$. In turn, the rate of embezzlement is constrained by the degree of scrutiny, which is determined by the rate of taxation.

This implies a maximum revenue available for patronage, somewhat analogous to a Laffer curve. The maximum is determined by:

$$
\begin{gathered}
P^{\max }=\operatorname{Max} e \cdot t \cdot Y . \\
\text { wrt } t
\end{gathered}
$$

subject to $e=e(t), e^{\prime}<0$.

To see the implication at its simplest, we linearize the inverse relationship between the embezzlement rate and the tax rate:

$$
e=\alpha(1-t)
$$

The society has an underlying rate of embezzlement, $\alpha$, which is curtailed by taxation. This underlying rate may differ greatly between societies, being determined by culture and history. Our analysis is pertinent in those societies where $\alpha$ is sufficiently high that taxation is material. However, evidence on public corruption (Friedman, Johnson, Kaufmann and Zoido-Lobaton, 2004) suggests that many societies do not have strong intrinsic defenses. 
The decision problem for the corrupt politician is thus:

$\max : \alpha(1-t) \cdot t \cdot Y$.

wrt $t$

At the patronage-maximizing tax rate, $t^{*}=0.5$, the resources available for patronage are:

$P=Y \alpha / 4$,

Thus, in this simple model, in a society with no intrinsic defenses $(\alpha=1)$ a dishonest politician would set taxes so as to generate public revenues that were half of GDP, and half of these revenues would be embezzled for political patronage. The scrutiny provoked by this level of taxation would defend the remaining half of the revenues from embezzlement and the politician would, albeit reluctantly, find that the most electorally cost-effective remaining use for these revenues was to spend them on the provision of public goods. More generally, the provision of public goods is:

$G=(2-\alpha) Y / 4$

Competitive electoral politics drives parties to adopt the most cost-effective strategy of winning votes, subject to the constraint imposed by endogenous scrutiny. Although politicians would like to retain the rents for themselves, in a competitive equilibrium parties must embezzle as much public revenue as possible and use it to bribe voters. 
Hence, (4) and (5), though extremely simple, describe the equilibrium outcome of electoral competition with the restraint of scrutiny endogenized.

The simplicity of the analysis enables the complication of resource rents to be introduced without the model becoming either intractable or opaque. We denote resource rents as a proportion of income by, $r$. The rents accrue directly to the government, augmenting its revenue from the taxation of citizens. We assume that the government is not able to ring-fence the revenue from resource rents from the prevailing public scrutiny of its tax revenue. This is not an unreasonable assumption. Citizen scrutiny amounts to the creation of processes such as budgets and audits which apply to all revenues regardless of their source: the government cannot choose which revenues are subject to scrutiny and which are not. The government is thus not free simply to spend all the resource rents on patronage. However, unlike taxation, the resource rents do not themselves provoke citizen scrutiny. This assumption is precisely analogous to that made in respect of aid by Brautigam and Knack (2004) and Moore (1998): citizens are only provoked into scrutiny by having money taken from them by government. Government revenue thus becomes:

$$
[t(1-r)+r] \cdot Y
$$

and the maximum patronage resources available to the government become:

$$
\max \alpha(1-t) \cdot[t(1-r)+r] \cdot Y
$$

wrt $t$ 
The patronage-maximizing tax rate is now:

$$
t^{* *}=(1-2 r) /(2-2 r)
$$

A corollary of (8) is that the higher is revenue from resource rents the lower is the tax rate. This relationship is manifest in developing countries: for example, the oil-rich economies have very low non-oil taxation. While this is usually interpreted as reflecting the reduced need for such taxation, it is notable that the same relationship does not seem to hold in the oil-rich developed economies. For example, Norway, which is the most oil-rich society in the OECD, has among the highest rates of non-oil taxation. Our model provides an alternative explanation for the phenomenon: where $\alpha$ is high (unlike in Norway), governments of oil-rich countries consciously set low tax rates so as not to provoke scrutiny of the oil revenues. ${ }^{1}$ In turn, this implies that the level of scrutiny is lower and so the rate of embezzlement is higher. More surprisingly, total chosen revenue as a share of income, $v$, is constant over the entire range $0 \leq \mathrm{r} \leq 0.5$ :

$$
v^{* *}=t^{* *}(1-r)+r=[(1-2 r) /(2-2 r)] \cdot[(1-r)+r]=0.5
$$

That is, until taxation is driven down to zero which occurs once resource rents exceed half of GDP. For a given total income, revenue for patronage rises as a result of resource rents not because the government commands more money, but because it is able to raise the same money while arousing less public scrutiny. As a result, less

\footnotetext{
${ }^{1}$ Half of all Nigerian oil revenues accrue to the Governors of the 36 states, all of which also have powers of local taxation: differences among states thus constitute a 'natural experiment'. In 2006 the Chief Economic Advisor to the President observed to Collier that the more corrupt the Governor the lower the tax rate he chose to set.
} 
needs to be diverted to the provision of public goods. A corollary of this is that over this range of resource rents, comparing two societies with the same level of income but with different shares of natural resource rents, the one with the higher share will have the worse provision of public goods.

Whether a resource discovery which augments income will nevertheless worsen the provision of public goods depends upon the scale of the resource discovery, $r$, and the value of $\alpha$. To see this it is useful to consider a resource discovery which precisely doubles national income, so that once the society gets the resource rents $r=0.5$. From (8) at this point the tax rate on the non-rent economy has been driven down to zero. Total government revenue has thus doubled: the state previously received half of national income and now it receives all the rents, worth the entire previous national income, but nothing else. The demise of taxation increases the rate of embezzlement from $\alpha / 2$ to $\alpha$. Hence, public goods provision in the presence of the rents, $G^{r}$ is:

$$
G^{r}=(1-\alpha) 2 Y \text {. }
$$

Comparing this with (5), there is a critical level of $\alpha$ above which public goods provision actually deteriorates, the critical rate being $\alpha=0.857$. For resource discoveries beyond $r=0.5$ there is no further scope for the reduction in taxation (unless, for example, sinecures in public employment are introduced), and so public goods provision unambiguously begins to improve. As noted, Norway is an example of a relatively small resource discovery in a society with a strong prior tradition of scrutiny, so that $\alpha$ was very small. Saudi Arabia is an example of a society were the resource discovery is so large that even though $\alpha$ is high, the provision of public 
goods has improved. Nigeria is an example of a society with a moderate-size discovery and a high initial value of $\alpha$, where the discovery has indeed probably worsened public goods provision: across a range of social indicators Nigeria is ranked below other African economies without resource rents.

While the direct focus of this model is on the provision of public goods, it has an ready extension to a more general measure of economic performance. Public goods are not predominantly consumed, they are in large measure capital expenditures which cannot easily be substituted by the private sector, such as education and infrastructure. Further, the entire model could readily be reformulated to include the provision of public policies which do not require expenditure but do require political effort. Politicians with dissonant interests would prefer the easy life but can be disciplined by tax-provoked scrutiny to supply good policies. In democracies without resource rents the costs of political effort become costs such politicians have to pay in order to raise revenues, some of which can then be embezzled. In equivalent resourcerich democracies politicians get the same total revenue with lower taxes and so are able to get away with lower policy effort. Thus, the result that for given income those resource-rich democracies that lack exogenously given scrutiny mechanisms, (a low value of $\alpha$, will have inferior public goods to similar resource-scarce democracies, readily extends to the entire range of public policies. A corollary is that ceteris paribus they would have inferior economic growth performance. Growth performance thus provides the most general testable formulation of our model. It predicts that, in the absence of exogenously low values of $\alpha$, resource-rich democracies would have significantly slower growth than resource-scarce democracies. Further, since autocracies are freed from the electoral competition that remorselessly drives such 
democracies to an equilibrium in which public goods and policies are inferior, resource-rich autocracies might out-perform equivalent democracies. These are the propositions which we now test.

\section{Natural Resource Rents and Democracy: Descriptive Statistics}

In order to test the relationship between resource rents, democracy, and growth, it is necessary to have a measure of resource rents. Usually, this concept has been proxied in the literature by primary commodity exports. However, this is a highly imperfect approximation and data are now available to enable the construction of a more accurate measure. In this Section we describe how this measure can be built, countryby-country and year-by-year, for the period 1970-2001. We then match this data against a quantitative measure of political rights for the same period.

Since we try to proxy 'rents' we did not want to rely on the commonly used SachsWarner measure of natural resources which is the ratio of primary commodity exports to GDP. Evidently, the share of export earnings accruing as rents differs radically both between commodities and over time depending upon the level of world prices. For example, when world coffee prices are low coffee exports will not generate rents whereas when oil prices are high most of the revenue will be rents. We therefore adopted a more precise measure of rents, using environmental economic data from the World Bank which included both costs of production and prices and so enabled us to

calculate natural resource rents as a percentage of GDP ${ }^{\mathrm{ii}}$. This calculation included several different steps. First, we defined rents as the difference between the natural resource price and the extraction costs. For example, for oil the World Bank database 
provides the average of four spot crude oil prices. Prices are global, thus they vary over time but are the same across countries. Extraction costs on the other hand vary over time as well as across countries. In a second step, we multiplied the natural resource rents per unit of output by the total volume extracted. We then added these total rents for a variety of natural resources: oil, gas, coal, lignite, bauxite, copper, iron, lead, nickel, phosphate, tin, zinc, silver and gold. ${ }^{\text {ii }}$ For each year we divided the sum of resource rents by GDP. Our regression analysis uses four year averages, so we averaged the data over 8 sub-periods: $1970-73,1974-77, \ldots, 1998-2001$. We were able to construct this rent variable for 969 panel data observations. A histogram of the natural resource rents as a percentage of GDP shows a heavily skewed frequency. A number of countries did not extract any of these natural resources (158 observations) and a large number only had small rents of less than one percent (363 observations). For 180 observations the natural resource rents were between one and five percent and 79 observations had rents between five and ten percent. We define countries with a natural resource rent percentage of ten or higher as high rent countries. Only 187 observations were in this range. ${ }^{\text {iv }}$

We proxy democracy by the Polity IV scoring of 'Democracy'. This is an 11 point ordinal scale, ranging from zero to ten. Higher values indicate a greater competition and openness of the democratic process. Although the measure is termed 'democracy', its criteria are essentially focused on electoral processes. Data are available for 1,004 observations. We measure democracy at the beginning of each sub-period. Since the democracy score is ordinal, all uses that treat it as cardinal are at best approximations. In our subsequent regression analysis we check the robustness of results that assume cardinality by replacing the democracy score with a binary 
measure partitioned by a threshold. Nevertheless, descriptive statistics that assume cardinality are a convenient introduction to the data. In Table 1 we show the means and standard deviations for the democracy scores. The first row provides these descriptive statistics for the entire sample period (1970-1998). The average democracy score for the entire sample is about 4 , whereas for countries with a high percentage of natural resources it is only around 1.5. However, the standard deviation is large compared with the entire sample, indicating that there is a wide dispersion of democracy scores among these countries. On average democracy scores have increased over time: for the entire sample the biggest increase occurred between 1986 and 1990 with the collapse of the Eastern Block. For the natural resource rich economies the increases have been less marked: by the end of the period their score was still only 1.9 as compared with 5.3 for the average country.

--- Table 1 about here ---

\section{Empirical Analysis}

Whether resource rents enhance or undermine the economic consequences of democracy is a priori ambiguous. We now use our measure of rents to investigate the issue empirically. We adopt the medium-term growth rate of the economy as our measure of economic performance. Since resource rents are largely depletable, the central policy issue in resource-rich societies is the transformation of depleting rents into more sustained forms of income. We take four-year periods as our units of 
observation to smooth out the noise of annual observations of growth rates. Evidently, in addition to any interaction effects with the political process, natural resource rents can be expected to have direct effects on growth and we will control for them.

We start from a simple specification which includes only the variables directly of interest, - the level of natural resource rents, and the level of democracy, - and a single conditioning variable, the level of per capita income (Table 2, column 1). Countries with an initially higher democracy score have on average higher growth rates. The coefficient on natural resource rents is insignificant. From this base we introduce the interaction term rents-democracy which is the focus of our analysis (column 2). The interaction term is negative and significant at the ten percent level. Democracy appears to enhance growth except in the presence of substantial natural resources. Around this simple specification we first investigate three variants. We allow for the possibility of diminishing returns to rents (column 3) but find no evidence of such non-linear effects. Second, we allow for lagged effects. The large case-study literature on natural resource rents has many examples of public expenditure being increased to unsustainable levels. When we lagged resource rents as a further explanatory variable (column 4), the term is significant, negative and substantial: resource rents indeed appear to generate unsustainable increases in the level of output. Third, since contemporaneous natural resource rents have no significant direct effect in this regression we investigate dropping the term in favor of this lagged effect (column 5). At this stage the interaction of democracy and resource rents is negative but not significant at conventional levels $(p=0.166)$.

--- Table 2 about here --- 
While democracy is most commonly understood in terms of competitive elections which determine how a government acquires power, a mature democracy also includes checks and balances which in various degrees constrain how a government can use power. This distinction is indeed central to the theory of Section 2. With an unconstrained government, electoral competition drives an economy into patronage politics. Only the checks and balances that are provoked by taxation force political actors to compete through the effective provision of national public goods. The role of taxation is important for the emergence of checks and balances because, unlike electoral competition, these themselves are public goods that are otherwise likely to be radically under-supplied. Elections are easy to introduce, as is evident from those held under the precarious conditions of Afghanistan and Iraq in 2005. This is partly because they are one-off events, and also because the incentives for parties to participate are strong: participation is the route to power. By contrast, checks and balances are not events but processes which must function continuously and so do not lend themselves to short but focused efforts. Further, not only are they public goods that nobody has a strong incentive to provide, but the actors with the power to create them have an active interest to resist them. Precisely because checks and balances are far more difficult to provide than electoral competition, democracies differ considerably in the balances between these two defining features. We therefore introduce a specific measure of checks and balances into the analysis in addition to the more general measure of democracy. We proxy the power of checks and balances by a measure used by Keefer and Stasavage (2004) termed 'checks'. As implied, this focuses on the ability of other agents to restrain the government. The index ranges from one (few veto players) to 17 (high number of veto players). Unlike the 
democracy index it is in principle cardinal, being a count of the number of veto players. Although the democracy score and the checks variable are correlated ( $\rho=0.72$ ), there is sufficient variation to include the two indices in the same regression. As can be seen from Figure 1 in the Appendix and consistent with our hypothesis that checks are considerably more difficult to provide than elections, there are no countries which have a low democracy score and a high number of checks. However, there is considerable variation across countries with above average democracy scores. Some have few or no veto players, whereas others have many: the country with the highest number of checks (17) is India, which also has a high democracy score.

Having distinguished between the two aspects of democracy we introduce an additional interaction term between resource rents and checks and balances. We also add the variable 'checks' itself, to control for any direct effect that it might have other than through its effect on the utilization of resource rents, the results being shown in Table 2, column 6. While the direct effect of checks is insignificant, the interaction of resource rents with checks and balances is positive and significant. Further, the adverse interaction effect of democracy and natural resources now becomes highly significant. Thus, whereas democracy per se is distinctively detrimental for resourcerich countries, checks are distinctively beneficial. In column 7 we drop the insignificant direct effect of checks with no change in the overall results. We now subject these results to four tests for robustness.

First, we replace democracy as a continuous variable with a dummy which takes the value of unity if the democracy score is greater than or equal to five (column 8). Our 
results remain unaffected: in particular, the interaction between democracy and natural resource rents is still negative and significant at the one percent level.

Second, we control for fixed effects. Since our model contains time invariant variables (continent dummies) and variables which are in general only changing slowly over time (political economy variables) we cannot estimate this model by conventional fixed effects. However, the technique of least squares dummy variables is equivalent to fixed effects (Hendry, Johansen and Santos., 2004). Following this procedure, we first included one third of all country dummies in our model as presented in column 7 and then repeated the estimation with each of the other thirds of the country dummies. Based on these three regressions we gathered all those country dummies which were significantly different from zero and re-estimated the model. ${ }^{\mathrm{v}}$ These results are shown in column 9. The coefficients and standard errors are similar to our pooled OLS regression and our core results remain significant at the one percent level. The main difference between the pooled results and the one including country dummies is that the coefficient on GDP per capita is slightly larger and the standard error is smaller, making GDP significant at the five percent level.

Third, we re-introduce the contemporaneous, direct effect of resource rents (column 10). Although our baseline regression of column 7 is close to being a differences-indifferences specification, the direct effect of natural resource rents is only included with a lag whereas the interaction term measures resource rents contemporaneously. We therefore replace lagged by contemporaneous natural resources so that the requirements for differences-in-differences are fully met. The coefficient on the interaction term is unchanged and is again statistically significant at one percent. 
Fourth, we attempt to allow for the potential endogeneity of democracy. We should note that since we are only concerned with the interaction effect of democracy, rather than its direct effect, this problem is less serious than were we attempting to infer a direct causal connection from democracy onto some outcome. The interaction effect is analogous to a difference-in-differences approach: does a difference in democracy have a different effect depending upon resource rents? However, to address remaining concerns we instrument for democracy. We use as an instrument the historical data on settler mortality (Acemoglu, Johnson and Robinson, 2000). Although Acemoglu, Johnson and Robinson use settler mortality to instrument for other types of institutions, settlers had an interest in encouraging political institutions that were representative of their interests, and as elsewhere, such institutions invite subsequent pressure to expand the franchise. Indeed, in their more recent work they argue that democracy is the outcome of a long institutional trajectory, rather than being generated by economic development (Acemoglu et al. 2008). Because of data limitations this instrumentation drastically reduces the size of our sample and so we economize on other variables. Nevertheless, so instrumented, the interaction of democracy and natural resource rents is negative and significant (Table 3). ${ }^{\mathrm{vi}}$

--- Table 3 about here ---

We also examined the possible endogeneity of our natural resource measure. An unobserved variable may be causing slow growth and low GDP. Since we measure natural resource rents as a percentage of GDP, it is possible that our estimates suffer from endogeneity bias. We tried two different approaches to tackle this issue. First, 
we use total rather than relative resource rents. The interaction term with democracy is negative and significant while the interaction term with checks and balances is positive and significant. Second, we use a product of a commodity price index and the quantity of sub-soil assets (Collier and Goderis, 2007a) as an instrument for natural resource rents. They argue that prices and the occurrence of natural resources can be considered as exogenous. Using this instrument the interaction terms are significant and have the same signs as before. ${ }^{\mathrm{vii}}$

These checks suggest that there is indeed a causal mechanism from the interaction of natural resources and democracy onto growth as hypothesized in Section 2, and provide some support for our choice of the model in column 7 as our baseline. Applying the coefficients on the two critical interaction terms, in a developing country at the $75^{\text {th }}$ percentile of the democracy score, (9), but with no checks and balances, each additional percentage point of GDP from natural resource rents reduces growth by 0.23 percentage points. For a given level of checks and balances, resource rents are more damaging if the country is democratic: taking a developing country with resource rents equal to $20 \%$ of GDP, if the country is switched from being at the $75^{\text {th }}$ percentile of the democracy score (9) to the $25^{\text {th }}$ percentile (0), its growth rate increases by 2.2 percentage points. By contrast, again for a given level of checks, in the absence of resource rents democracy is good for growth: taking a developing country without resource rents, if it is switched from the $25^{\text {th }}$ percentile of the democracy score to the $75^{\text {th }}$ percentile, its growth rate increases by 1.31 percentage points. The critical level of natural resource rents beyond which democracy becomes dysfunctional for growth, for given checks, is 7.44 percent of GDP. While these are the central estimates from variables that are statistically significant, we should note 
that the confidence intervals are nevertheless substantial. For example, the reduction of 0.23 percentage points due to an additional one percent resource rents has a $95 \%$ confidence interval of 0.12 to 0.34 percentage points.

Within the basic structure of electoral competition being distinctively detrimental and checks and balances being distinctively beneficial, we now investigate the routes by which resource rents undermine the economy and hence the behavior that checks and balances inhibits. Our approach is to control for possible routes to see whether the interaction effects lose economic and statistical significance. The regressions with these controls are presented in Table 4, and for ease of reference Table 4, column 1 repeats are baseline regression.

--- Table 4 about here ---

It is known that democracy tends to reduce the share in investment in GDP (Tavares and Wacziarg, 2001) and that countries with a high dependency on natural resources have a low investment share (Gylfason and Zoega, 2006). Since investment is likely to be central to the transformation of resource rents into sustained growth, potentially democracy is detrimental due to underinvestment. To test this we control for the share of investment in GDP (Table 4, column 2). Unsurprisingly, investment is positive and significant at the one percent level. However, its inclusion has virtually no effect. The coefficients on both the democracy·rents interaction and the checks rents interaction barely change value and remain significant. Thus, to the extent that growth is driven by investment, democracy must be undermining growth in the resource-rich countries through the quality of investment rather than its quantity. 
We next control for public consumption (Table 4, column 3). As is commonly found in the growth literature, government consumption expenditure is negative. However, this has no effect on either the significance of the core interaction terms, or the magnitude of their coefficients. Thus, the route by which democracy undermines the growth effects of resource rents is not that public spending becomes inflated. Again, to the extent that public spending matters for the growth process, resource rents must be undermining the quality of spending rather than inflating its quantity. This result is consistent with the somewhat counter-intuitive theoretical prediction of (9) above: resource rents induce a shift in the composition of public spending away from public goods towards patronage goods, rather than an increase in overall spending. These results are also consistent with the corollary proposition that resource rents are used to reduce taxation.

We next control for the effect of ethnic diversity. Previous studies have found that ethnic diversity is detrimental to growth (Easterly and Levine, 1997), but that this effect is reduced by democracy (Collier, 2000). This benign interaction effect of democracy is thus the opposite of the malign effect we have so far found. A probable explanation for it is that autocracy is liable to be particularly damaging in the context of ethnic diversity: if power is narrowly based on an ethnic support group redistribution dominates the public good of growth. We now bring the two effects together (Table 4, columns 6-9). We use a new measure of diversity proposed by Alesina et al (2003), which classifies ethnic groups according to their racial and linguistic characteristics. Consistent with previous research, the direct effect of ethnic diversity on growth is adverse, and its interaction with democracy is positive. 
However, controlling for these effects has no effect on either the significance or the size of the coefficients of the two core interaction terms. Thus, whatever the route by which natural resource rents undermine the growth process in a democracy, it does not run through ethnic diversity.

Finally, we test our results against the superficially similar 'voracity effect' of Tornell and Lane (1999). They also predict adverse consequences of resource rents on growth in the context of patronage politics. However, in their model the problem is generated by the uncoordinated 'gauging' of multiple powerful groups, restrained only by concern for a participation constraint. Resource rents ease the participation constraint and induce an increase in gauging greater than the value of the rents, this being the voracity effect. A testable difference between the two explanations is that the voracity effect is at its peak when there are only two powerful groups in the society, each able to gauge. In this situation the cost of rent extraction is predicted to be double the value of the rents themselves. There is no voracity effect either when the political system is autocratic, or when it is fully competitive with multiple groups each holding some power. In contrast, our model predicts that as electoral competition increases the costs of resource rents continue to mount. The Tornell-Lane model thus predicts that the effect of the political system on the use of resource rents is non-monotonic. We test for this by adding the square of the democracy score interacted with resource rents as an additional variable (Table 4, column 5). Evidently, since the democracy score is ordinal, all rank-preserving transformations have equal validity. However, for the Tornell-Lane hypothesis to hold this term should be significantly positive. In fact it is completely insignificant. We have also tested using dummy variables to capture break points in the democracy scores and found no evidence that the relationship is non- 
monotonic. There is no sign that as political competition intensifies the problem of resource rents is diminished, rather it continues to get worse.

We now turn to our prediction that in resource-rich democracies the mechanisms of scrutiny would be systematically weakened: due to low taxation citizens would not be provoked into supplying the public good of scrutiny. We test whether checks and balances are differentially eroded by resource rents. For completeness, we also analyze whether resource rents tend to reduce democracy itself, an effect already established for oil economies by Ross (2001).

We begin with a simple OLS specification in which the level of checks and balances and democracy are each explained by the level of per capita GDP, and time dummy variables, and the lagged value of natural resource rents (Table 5). For both checks and balances and democracy the lagged value of resource rents is highly significant and negative. Further, as the lag is progressively lengthened from one period (four years) to two periods (eight years) to seven periods (28 years), the significance level and the size of the coefficient increase. The effects are large: after 28 years a country with mean income but with resource rents worth $30 \%$ of GDP would have a checks score in the 22 th percentile instead of in the $34^{\text {th }}$ percentile, and a democracy score in the 25 th percentile instead of in the $40^{\text {th }}$ percentile.

--- Table 5 about here --- 
While the OLS results are suggestive, they are open to multiple interpretations. In Table 6 we check robustness by switching the dependent variable to the changes in checks and democracy, respectively, over various periods, controlling for both their initial level and per capita GDP. Again, resource rents significantly erode both checks and democracy. These results are consistent with the predictions of the model and also with Ross (2001).

---Table 6 about here ---

Overall, our results suggest that the form of democratic polity best-suited to resourcerich countries is one with checks and balances that are strong relative to electoral competition. This is indeed the form of democracy in the most striking exception to generally adverse combination of democracy and resource rents, namely Botswana. Electoral competition is in practice quite limited: the government has never been defeated at the polls. Yet, perhaps because the democracy has been continuous since independence, the legal and bureaucratic procedures that constitute checks and balances have been maintained. Other examples of democracies that have had relatively strong checks and reasonable economic performance are Papua New Guinea, Chile and Mexico. These polities contrast with many of the 'instant' and often externally driven democracies that swept across Africa and Central Asia following the collapse of the Soviet Union. This is indeed the form of democracy in the most striking exception to generally adverse combination of democracy and resource rents, namely Botswana. Electoral competition is in practice quite limited: the government has never been defeated at the polls. Yet, perhaps because the 
democracy has been continuous since independence, the legal and bureaucratic procedures that constitute checks and balances have been maintained.

\section{Conclusion}

Resource-rich countries have tended to be autocratic and also have tended to use their resource wealth badly. The neoconservative agenda of promoting democratization in resource-rich countries thus offers the hopeful prospect of a better use of their economic opportunities. Our analysis has tested whether this hopeful prognosis is likely to be borne out.

We first showed that a priori the effect of natural resources on the economic consequences of democracy is ambiguous. While there are plausible mechanism that would support the proposition that resource rents enhance the benefits of democracy, the opposite might also hold. We set out a simple model of democratic politics in which we distinguish between two dimensions of democracy, electoral competition and checks and balances. By undermining checks and balances, resource rents unleash patronage politics and in these conditions electoral competition is economically damaging.

Using new data on the value of resource rents, we then tested these propositions. We found that in developing countries the combination of resource rents and democracy has been significantly growth-reducing. In the absence of resource rents democracies 
outperform autocracies, in the presence of large resource rents autocracies outperform democracies. We found that this result was robust to controlling for the potential endogeneity of democracy and was also robust to fixed effects. We found that the antidote to these adverse effects of democracy was intensified checks and balances.

While countries with large resource rents need checks and balances, this is not what they get. Resource rents tend gradually to undermine checks and balances. Thus, in those developing societies where the state has most command over resources, the democratic process has been least effective at controlling them for the public good. The implication for the neoconservative agenda is that it either needs to be scaled down or scaled up. On the criterion of economic performance targeting electoral competition on the resource-rich societies appears to be particularly inappropriate unless it is complemented by checks and balances. Unfortunately, whereas electoral competition is easy to establish since there are strong incentives for participation, checks and balances are public goods liable to be undersupplied. 


\section{Tables}

\section{Table 1: Democracy Scores}

\begin{tabular}{lll}
\hline Period & Sample & $\begin{array}{l}\text { High Natural Rents } \\
\text { Countries }\end{array}$ \\
$1970-1998$ & $4.03(4.26)$ & $1.46(3.11)$ \\
1970 & $3.29(4.16)$ & $0.96(2.56)$ \\
1974 & $3.08(4.22)$ & $0.89(2.56)$ \\
1978 & $3.18(4.28)$ & $1.32(3.09)$ \\
1982 & $3.43(4.29)$ & $1.76(3.41)$ \\
1986 & $3.72(4.35)$ & $1.28(3.08)$ \\
1990 & $4.52(4.27)$ & $1.89(3.49)$ \\
1994 & $5.29(3.96)$ & $2.00(3.48)$ \\
1998 & $5.26(3.98)$ & $1.92(3.43)$ \\
\hline
\end{tabular}

Notes: Standard Deviation in parentheses. 
Table 2: Growth, Democracy and Natural Resource Rents

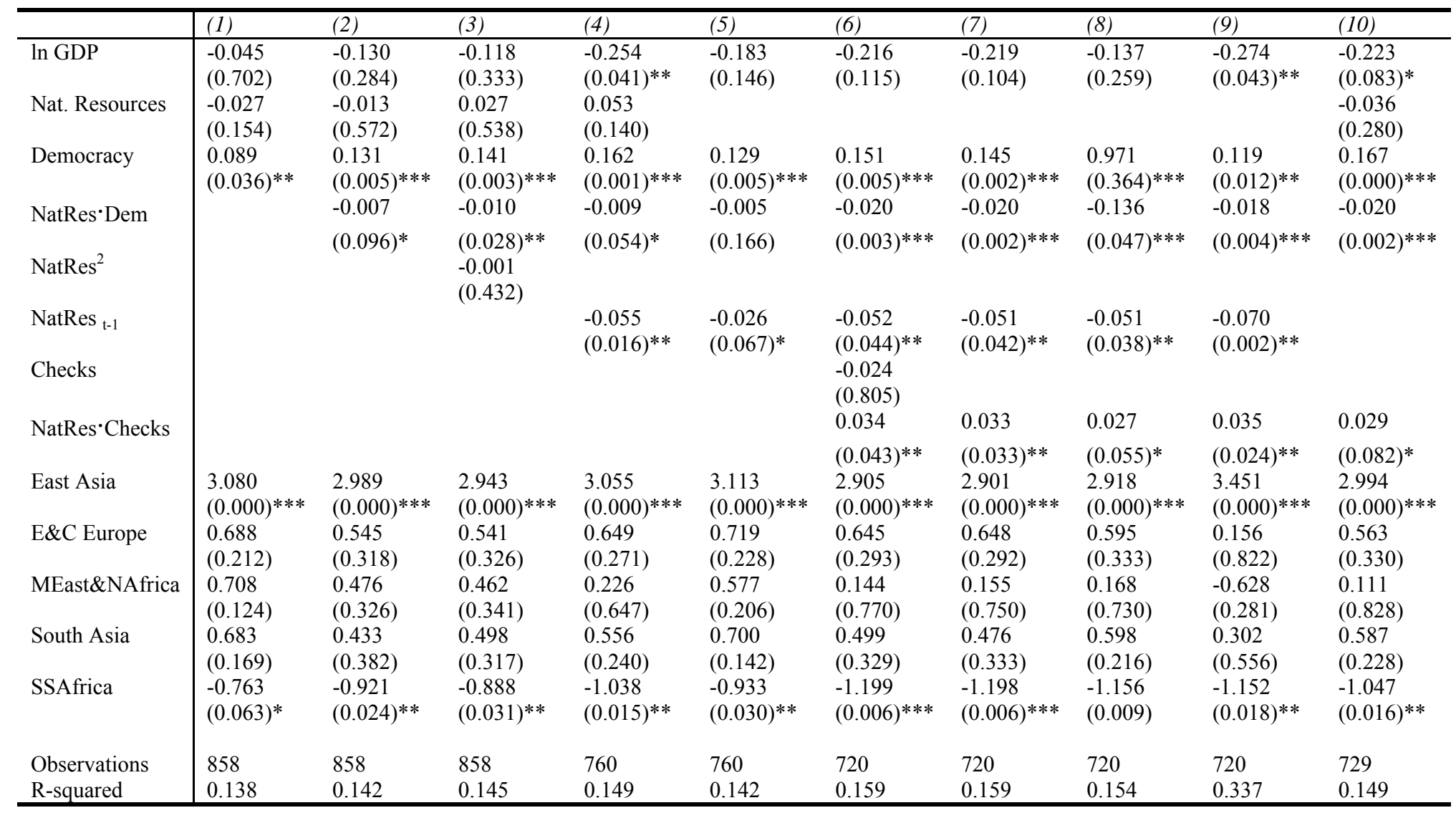

Notes: Dependent variable: average annual growth. Robust $\mathrm{p}$ values in parentheses, ${ }^{*}$ significant at $10 \%$; $* *$ significant at $5 \%$; $* * *$ significant at $1 \%$, regressions include time dummies (not reported) 
Table 3: Growth, Democracy and Natural Resource Rents - 2SLSQ

\begin{tabular}{l|ll}
\hline & $1^{\text {st }}$ stage & $2^{\text {nd }}$ stage \\
\hline Dependent Variable & Democracy & Growth \\
ln GDP & 0.977 & -0.495 \\
& $(0.000)^{* * *}$ & $(0.370)$ \\
Nat. Res. & 0.019 & 0.036 \\
Democracy & $(0.294)$ & $(0.161)$ \\
ln Settler Mortality & & 0.542 \\
& -0.560 & $(0.156)$ \\
NatRes Democracy & $(0.004)^{* * *}$ & \\
Residual & & -0.011 \\
East Asia & & $(0.012)^{* *}$ \\
MEast\&NAfrica & & -0.486 \\
South Asia & -3.963 & $(0.207)$ \\
SSAfrica & $(0.000)^{* * *}$ & 5.406 \\
& -4.903 & $(0.000)^{* * *}$ \\
Observations & $(0.000)^{* * *}$ & 2.908 \\
R-squared & 1.606 & $(0.116)$ \\
\hline
\end{tabular}

Notes: 2SLQ regression. Robust $\mathrm{p}$ values in parentheses, $*$ significant at $10 \%$; $* *$ significant at $5 \%$; *** significant at $1 \%$, regressions include time dummies (not reported) 
Table 4: Growth, Democracy and Scrutiny

\begin{tabular}{|c|c|c|c|c|c|}
\hline & (1) & (2) & (3) & (4) & (5) \\
\hline $\ln$ GDP & $\begin{array}{l}-0.219 \\
(0.104)\end{array}$ & $\begin{array}{l}-0.511 \\
(0.001) * * *\end{array}$ & $\begin{array}{l}-0.160 \\
(0.269)\end{array}$ & $\begin{array}{l}-0.166 \\
(0.240)\end{array}$ & $\begin{array}{l}-0.216 \\
(0.106)\end{array}$ \\
\hline Nat. Resources $\mathrm{t}_{\mathrm{t}-1}$ & $\begin{array}{l}-0.051 \\
(0.042)^{* *}\end{array}$ & $\begin{array}{l}-0.052 \\
(0.105)\end{array}$ & $\begin{array}{l}-0.050 \\
(0.052)^{*}\end{array}$ & $\begin{array}{l}-0.050 \\
(0.044) * *\end{array}$ & $\begin{array}{l}-0.051 \\
(0.044)^{* *}\end{array}$ \\
\hline Democracy & $\begin{array}{l}0.145 \\
(0.002) * * *\end{array}$ & $\begin{array}{l}0.147 \\
(0.003) * * *\end{array}$ & $\begin{array}{l}0.152 \\
(0.003) * * *\end{array}$ & $\begin{array}{l}-0.049 \\
(0.486)\end{array}$ & $\begin{array}{l}0.142 \\
(0.003) * * *\end{array}$ \\
\hline NatRes $\cdot$ Dem & $\begin{array}{l}-0.020 \\
(0.002)^{* * *}\end{array}$ & $\begin{array}{l}-0.018 \\
(0.002)^{* * *}\end{array}$ & $\begin{array}{l}-0.020 \\
(0.001)^{* * *}\end{array}$ & $\begin{array}{l}-0.020 \\
(0.003)^{* * *}\end{array}$ & $\begin{array}{l}-0.035 \\
(0.264)\end{array}$ \\
\hline NatRes $\cdot$ Checks & $\begin{array}{l}0.033 \\
(0.033)^{* *}\end{array}$ & $\begin{array}{l}0.032 \\
(0.036) * *\end{array}$ & $\begin{array}{l}0.034 \\
(0.029)^{* *}\end{array}$ & $\begin{array}{l}0.035 \\
(0.036) * *\end{array}$ & $\begin{array}{l}0.033 \\
(0.034)^{* *}\end{array}$ \\
\hline ln Investment & & $\begin{array}{l}1.485 \\
(0.000) * * *\end{array}$ & & & \\
\hline Gov cons. & & & $\begin{array}{l}-0.034 \\
(0.216)\end{array}$ & & \\
\hline Ethnicity & & & & $\begin{array}{l}-3.901 \\
(0.000)^{* * *}\end{array}$ & \\
\hline Ethnicity $\cdot$ Dem & & & & $\begin{array}{l}0.401 \\
(0.001) * * *\end{array}$ & \\
\hline NatRes*Dem ${ }^{2}$ & & & & & $\begin{array}{l}0.002 \\
(0.584)\end{array}$ \\
\hline East Asia & $\begin{array}{l}2.901 \\
(0.000) * * *\end{array}$ & $\begin{array}{l}2.173 \\
(0.000) * * *\end{array}$ & $\begin{array}{l}2.811 \\
(0.000) * * *\end{array}$ & $\begin{array}{l}2.954 \\
(0.000) * * *\end{array}$ & $\begin{array}{l}2.959 \\
(0.000) * * *\end{array}$ \\
\hline E\&C Europe & $\begin{array}{l}0.648 \\
(0.292)\end{array}$ & $\begin{array}{l}0.299 \\
(0.633)\end{array}$ & $\begin{array}{l}0.721 \\
(0.243)\end{array}$ & $\begin{array}{l}0.528 \\
(0.390)\end{array}$ & $\begin{array}{l}0.717 \\
(0.225)\end{array}$ \\
\hline MEast\&NAfrica & $\begin{array}{l}0.155 \\
(0.750)\end{array}$ & $\begin{array}{l}0.135 \\
(0.771)\end{array}$ & $\begin{array}{l}0.320 \\
(0.520)\end{array}$ & $\begin{array}{l}-0.037 \\
(0.939)\end{array}$ & $\begin{array}{l}0.173 \\
(0.721)\end{array}$ \\
\hline South Asia & $\begin{array}{l}0.476 \\
(0.333)\end{array}$ & $\begin{array}{l}0.158 \\
(0.747)\end{array}$ & $\begin{array}{l}0.412 \\
(0.403)\end{array}$ & $\begin{array}{l}0.604 \\
(0.244)\end{array}$ & $\begin{array}{l}0.503 \\
(0.300)\end{array}$ \\
\hline SSAfrica & $\begin{array}{l}-1.198 \\
(0.006) * * *\end{array}$ & $\begin{array}{l}-0.723 \\
(0.103)\end{array}$ & $\begin{array}{l}-1.053 \\
(0.024)^{* *}\end{array}$ & $\begin{array}{l}-0.244 \\
(0.598)\end{array}$ & $\begin{array}{l}-1.175 \\
(0.007)^{* * *}\end{array}$ \\
\hline Observations & 720 & 686 & 713 & 718 & 720 \\
\hline R-squared & 0.159 & 0.197 & 0.163 & 0.181 & 0.159 \\
\hline
\end{tabular}

Notes: Dependent variable: average annual growth. Robust $\mathrm{p}$ values in parentheses, $*$ significant at $10 \% ; * *$ significant at $5 \% ; * * *$ significant at $1 \%$, regressions include time dummies (not reported) 
Table 5: Checks and Natural Resource Rents

\begin{tabular}{|c|c|c|c|c|c|c|c|}
\hline & (1) & (2) & (3) & (4) & (5) & (6) & (7) \\
\hline $\ln$ GDP & $\begin{array}{l}0.511 \\
(0.000)^{* * *}\end{array}$ & & & & & & \\
\hline NatRes & $\begin{array}{l}-0.029 \\
(0.000)^{* * *}\end{array}$ & & & & & & \\
\hline $\ln \mathrm{GDP}_{\mathrm{t}-1}$ & & $\begin{array}{l}0.495 \\
(0.000) * * *\end{array}$ & & & & & \\
\hline NatRes $_{t-1}$ & & $\begin{array}{l}-0.023 \\
(0.000)^{* * *}\end{array}$ & & & & & \\
\hline $\ln \mathrm{GDP}_{\mathrm{t}-2}$ & & & $\begin{array}{l}0.496 \\
(0.000)^{* * *}\end{array}$ & & & & \\
\hline NatRes $_{t-2}$ & & & $\begin{array}{l}-0.030 \\
(0.000)^{* * *}\end{array}$ & & & & \\
\hline $\ln \mathrm{GDP}_{\mathrm{t}-3}$ & & & & $\begin{array}{l}0.466 \\
(0.000)^{* * *}\end{array}$ & & & \\
\hline NatRes $_{t-3}$ & & & & $\begin{array}{l}-0.031 \\
(0.000)^{* * *}\end{array}$ & & & \\
\hline $\ln \mathrm{GDP}_{\mathrm{t}-4}$ & & & & & $\begin{array}{l}0.417 \\
(0.000)^{* * *}\end{array}$ & & \\
\hline NatRes $_{t-4}$ & & & & & $\begin{array}{l}-0.035 \\
(0.000)^{* * *}\end{array}$ & & \\
\hline $\ln \mathrm{GDP}_{\mathrm{t}-5}$ & & & & & & $\begin{array}{l}0.322 \\
(0.001)^{* * *}\end{array}$ & \\
\hline NatRes $_{t-5}$ & & & & & & $\begin{array}{l}-0.036 \\
(0.000)^{* * *}\end{array}$ & \\
\hline $\ln \mathrm{GDP}_{\mathrm{t}-6}$ & & & & & & & $\begin{array}{l}0.179 \\
(0.229)\end{array}$ \\
\hline NatRes $_{t-6}$ & & & & & & & $\begin{array}{l}-0.037 \\
(0.000)^{* * *}\end{array}$ \\
\hline Observations & 758 & 645 & 518 & 402 & 294 & 191 & 96 \\
\hline R-squared & 0.306 & 0.279 & 0.259 & 0.225 & 0.172 & 0.117 & 0.059 \\
\hline
\end{tabular}

Table 5a: Democracy and Natural Resource Rents

\begin{tabular}{|c|c|c|c|c|c|c|c|}
\hline & $\overline{(1)}$ & (2) & (3) & (4) & (5) & (6) & (7) \\
\hline $\ln$ GDP & $\begin{array}{l}1.682 \\
(0.000)^{* * *}\end{array}$ & & & & & & \\
\hline NatRes & $\begin{array}{l}-0.068 \\
(0.000)^{* * *}\end{array}$ & & & & & & \\
\hline $\ln \mathrm{GDP}_{\mathrm{t}-1}$ & & $\begin{array}{l}1.701 \\
(0.000)^{* * *}\end{array}$ & & & & & \\
\hline NatRes $_{t-1}$ & & $\begin{array}{l}-0.065 \\
(0.000)^{* * *}\end{array}$ & & & & & \\
\hline $\ln \mathrm{GDP}_{\mathrm{t}-2}$ & & & $\begin{array}{l}1.717 \\
(0.000)^{* * *}\end{array}$ & & & & \\
\hline NatRes $_{t-2}$ & & & $\begin{array}{l}-0.092 \\
(0.000)^{* * *}\end{array}$ & & & & \\
\hline $\ln \mathrm{GDP}_{\mathrm{t}-3}$ & & & & $\begin{array}{l}1.688 \\
(0.000) * * *\end{array}$ & & & \\
\hline NatRes $_{t-3}$ & & & & $\begin{array}{l}-0.098 \\
(0.000)^{* * *}\end{array}$ & & & \\
\hline $\ln \mathrm{GDP}_{\mathrm{t}-4}$ & & & & & $\begin{array}{l}1.649 \\
(0.000)^{* * *}\end{array}$ & & \\
\hline NatRes $_{t-4}$ & & & & & $\begin{array}{l}-0.112 \\
(0.000)^{* * *}\end{array}$ & & \\
\hline $\ln \mathrm{GDP}_{\mathrm{t}-5}$ & & & & & & $\begin{array}{l}1.528 \\
(0.000)^{* * *}\end{array}$ & \\
\hline NatRes $_{t-5}$ & & & & & & $\begin{array}{l}-0.124 \\
(0.000)^{* * *}\end{array}$ & \\
\hline $\ln \mathrm{GDP}_{\mathrm{t}-6}$ & & & & & & & $\begin{array}{l}1.586 \\
(0.000) * * *\end{array}$ \\
\hline NatRes ${ }_{t-6}$ & & & & & & & $\begin{array}{l}-0.144 \\
(0.000) * * *\end{array}$ \\
\hline Observations & 762 & 635 & 506 & 393 & 287 & 186 & 91 \\
\hline R-squared & 0.487 & 0.493 & 0.518 & 0.528 & 0.524 & 0.488 & 0.515 \\
\hline
\end{tabular}

Notes: Dependent variable: Democracy. Robust p values in parentheses, * significant at $10 \%$; ** significant at $5 \%$; $* * *$ significant at $1 \%$, regressions include time dummies (not reported) 
Table 6: Change in Checks and Natural Resource Rents

\begin{tabular}{|c|c|c|c|c|c|c|}
\hline $\ln \mathrm{GDP}_{\mathrm{t}-1}$ & $\begin{array}{l}(1) \\
\text { Checks- } \\
\text { Checks }_{\text {t-1 }} \\
0.157 \\
(0.003)^{* * *}\end{array}$ & $\begin{array}{l}(2) \\
\text { Checks- } \\
\text { Checks }{ }_{t-2}\end{array}$ & $\begin{array}{l}(3) \\
\text { Checks - } \\
\text { Checks }{ }_{t-3}\end{array}$ & $\begin{array}{l}(4) \\
\text { Checks- } \\
\text { Checks t-4 }\end{array}$ & $\begin{array}{l}\text { (5) } \\
\text { Checks- } \\
\text { Checks }{ }_{\text {t-5 }}\end{array}$ & $\begin{array}{l}\text { (6) } \\
\text { Checks- } \\
\text { Checks t-6 }\end{array}$ \\
\hline Checks $\mathrm{s}_{\mathrm{t}-1}$ & $\begin{array}{l}-0.384 \\
(0.000)^{* * *}\end{array}$ & & & & & \\
\hline NatREs $_{t-1}$ & $\begin{array}{l}-0.012 \\
(0.000)^{* * *}\end{array}$ & & & & & \\
\hline $\ln \mathrm{GDP}_{\mathrm{t}-2}$ & & $\begin{array}{l}0.214 \\
(0.004)^{* * * *}\end{array}$ & & & & \\
\hline Checks $_{\mathrm{t}-2}$ & & $\begin{array}{l}-0.500 \\
(0.000)^{* * *}\end{array}$ & & & & \\
\hline NatREs $_{t-2}$ & & $\begin{array}{l}-0.017 \\
(0.000)^{* * *}\end{array}$ & & & & \\
\hline $\ln \mathrm{GDP}_{\mathrm{t}-3}$ & & & $\begin{array}{l}0.234 \\
(0.010)^{* *}\end{array}$ & & & \\
\hline Checks $_{\mathrm{t}-3}$ & & & $\begin{array}{l}-0.563 \\
(0.000)^{* * *}\end{array}$ & & & \\
\hline NatREs $_{t-3}$ & & & $\begin{array}{l}-0.022 \\
(0.000)^{* * *}\end{array}$ & & & \\
\hline $\ln \mathrm{GDP}_{\mathrm{t}-4}$ & & & & $\begin{array}{l}0.222 \\
(0.066)^{*}\end{array}$ & & \\
\hline Checks $_{\mathrm{t}-4}$ & & & & $\begin{array}{l}-0.617 \\
(0.000)^{* * *}\end{array}$ & & \\
\hline NatREs $_{t-4}$ & & & & $\begin{array}{l}-0.025 \\
(0.000)^{* * *}\end{array}$ & & \\
\hline $\ln \mathrm{GDP}_{\mathrm{t}-5}$ & & & & & $\begin{array}{l}0.120 \\
(0.574)\end{array}$ & \\
\hline Checks $_{\mathrm{t}-5}$ & & & & & $\begin{array}{l}-0.608 \\
(0.018)^{* *}\end{array}$ & \\
\hline NatREs $_{t-5}$ & & & & & $\begin{array}{l}-0.022 \\
(0.014)^{* *}\end{array}$ & \\
\hline $\ln \mathrm{GDP}_{\mathrm{t}-6}$ & & & & & & $\begin{array}{l}-0.112 \\
(0.766)\end{array}$ \\
\hline Checks $_{\mathrm{t}-6}$ & & & & & & $\begin{array}{l}-0.415 \\
(0.292)\end{array}$ \\
\hline NatREs $_{\mathrm{t}-6}$ & & & & & & $\begin{array}{l}-0.016 \\
(0.352)\end{array}$ \\
\hline Observations & 626 & 497 & 381 & 272 & 168 & 77 \\
\hline $\mathrm{R}$-squared & 0.182 & 0.200 & 0.190 & 0.191 & 0.197 & 0.139 \\
\hline
\end{tabular}

Notes: Dependent variable: Change in Checks. Robust $\mathrm{p}$ values in parentheses, ${ }^{*}$ significant at $10 \%$; ** significant at $5 \% ;{ }^{* *}$ significant at $1 \%$, regressions include time dummies (not reported) 
Table 6a: Change in Democracy and Natural Resource Rents

\begin{tabular}{|c|c|c|c|c|c|c|c|}
\hline & (1) & (2) & (3) & (4) & (5) & (6) & (7) \\
\hline $\ln \mathrm{GDP}_{\mathrm{t}-1}$ & $\begin{array}{l}\text { Dem-Dem } \\
0.372 \\
(0.000)^{* * *}\end{array}$ & Dem-Dem $_{t-2}$ & Dem -Dem ${ }_{t-3}$ & Dem-Dem ${ }_{t-4}$ & Dem-Dem $_{\mathrm{t}-5}$ & Dem-Dem $_{\mathrm{t}-6}$ & Dem-Dem ${ }_{t-7}$ \\
\hline Democracy $_{\mathrm{t}-1}$ & $\begin{array}{l}-0.212 \\
(0.000)^{* * *}\end{array}$ & & & & & & \\
\hline NatRes $_{t-1}$ & $\begin{array}{l}-0.025 \\
(0.000)^{* * *}\end{array}$ & & & & & & \\
\hline $\ln \mathrm{GDP}_{\mathrm{t}-2}$ & & $\begin{array}{l}0.636 \\
(0.000) * * *\end{array}$ & & & & & \\
\hline Democracy $_{\mathrm{t}-2}$ & & $\begin{array}{l}-0.390 \\
(0.000)^{* * *}\end{array}$ & & & & & \\
\hline NatRes $_{t-2}$ & & $\begin{array}{l}-0.045 \\
(0.000) * * *\end{array}$ & & & & & \\
\hline $\ln \mathrm{GDP}_{\mathrm{t}-3}$ & & & $\begin{array}{l}0.905 \\
(0.000)^{* * *}\end{array}$ & & & & \\
\hline Democracy $_{\mathrm{t}-3}$ & & & $\begin{array}{l}-0.545 \\
(0.000)^{* * *}\end{array}$ & & & & \\
\hline NatRes $_{t-3}$ & & & $\begin{array}{l}-0.071 \\
(0.000)^{* * *}\end{array}$ & & & & \\
\hline $\ln \mathrm{GDP}_{\mathrm{t}-4}$ & & & & $\begin{array}{l}1.083 \\
(0.000) * * *\end{array}$ & & & \\
\hline Democracy $_{\mathrm{t}-4}$ & & & & $\begin{array}{l}-0.642 \\
(0.000)^{* * *}\end{array}$ & & & \\
\hline NatRes $_{t-4}$ & & & & $\begin{array}{l}-0.084 \\
(0.000)^{* * *}\end{array}$ & & & \\
\hline $\ln \mathrm{GDP}_{\mathrm{t}-5}$ & & & & & $\begin{array}{l}1.172 \\
(0.000) * * *\end{array}$ & & \\
\hline Democracy $_{\mathrm{t}-5}$ & & & & & $\begin{array}{l}-0.721 \\
(0.000) * * *\end{array}$ & & \\
\hline NatRes $_{t-5}$ & & & & & $\begin{array}{l}-0.094 \\
(0.000) * * *\end{array}$ & & \\
\hline $\ln \mathrm{GDP}_{\mathrm{t}-6}$ & & & & & & $\begin{array}{l}1.161 \\
(0.000) * * *\end{array}$ & \\
\hline Democracy $_{\mathrm{t}-6}$ & & & & & & $\begin{array}{l}-0.752 \\
(0.000)^{* * *}\end{array}$ & \\
\hline NatRes ${ }_{t-6}$ & & & & & & $\begin{array}{l}-0.106 \\
(0.000) * * *\end{array}$ & \\
\hline $\ln \mathrm{GDP}_{\mathrm{t}-7}$ & & & & & & & $\begin{array}{l}1.238 \\
(0.000)^{* * *}\end{array}$ \\
\hline Democracy $_{\mathrm{t}-7}$ & & & & & & & $\begin{array}{l}-0.745 \\
(0.000)^{* * *}\end{array}$ \\
\hline NatRes $_{t-7}$ & & & & & & & $\begin{array}{l}-0.124 \\
(0.000)^{* * * *}\end{array}$ \\
\hline Observations & 710 & 579 & 472 & 368 & 268 & 176 & 86 \\
\hline R-squared & 0.149 & 0.243 & 0.349 & 0.420 & 0.463 & 0.478 & 0.488 \\
\hline
\end{tabular}

Notes: Dependent variable: Change in Democracy. Robust $\mathrm{p}$ values in parentheses, ${ }^{*}$ significant at $10 \% ; * *$ significant at 5\%; *** significant at $1 \%$, regressions include time dummies (not reported) 


\section{References}

Auty, R. (ed.) 2001. Resource Abundance and Economic Development. Oxford, Oxford University Press.

Acemoglu, D., S. Johnson and J. Robinson. 2000. The Colonial Origins of Comparative Development: An Empirical Investigation, American Economic Review 91: 1369-1401.

Acemoglu, D., S. Johnson, J.A. Robinson and P. Yared. 2008. Income and Democracy. American Economic Review, forthcoming.

Alesina, Alberto, Arnaud Devleeschauwer, William Easterly, Sergio Kurlat, and Romain Wacziarg. 2003. Fractionalization. Journal of Economic Growth 8 (2): 155 194.

Alesina, Alberto, and Eliana La Ferrera. 2004. Ethnic Diversity and Economic Performance. Journal of Economic Literature 43:762-800.

Barro, R.J. 1996. Democracy and growth. Journal of Economic Growth 1: 1-27.

Beck, T., Clarke, G., Groff, A., Keefer, P. and P. Walsh. 2001. New tools in comparative political economy: The Database of Political Institutions. World Bank Economic Review 15(1): 165-176.

Besley, T., 2006, Principled Agents? Oxford University Press, New York.

Brautigam, D. and S. Knack. 2004 Foreign Aid, Institutions and Governance in SubSaharan Africa, Economic Development and Cultural Change 52: 255-285.

Collier, Paul. 2000. Ethnicity, Politics and Economic Performance. Economics and Politics 12 (3):225-245.

Collier, Paul and Benedikt Goderis. 2007. Prospects for Commodity Exporters: Hunky Dory or Humpty Dumpty? World Economics 8:1-15.

Collier, Paul and Benedikt Goderis. 2007a. Commodity Prices, Growth, and the Natural Resource Curse: Reconciling a Conundrum. University of Oxford. Mimeo.

Corden, W. Max, and J. Peter Neary, "Booming Sector and De-Industrialization in a Small Open Economy," The Economic Journal 92 (1982), 825-848.

Drazen, A. 2000. Political Economy in Macroeconomics. Princeton, New Jersey: Princeton University Press.

Easterly, William and Ross Levine. 1997. Africa's Growth Tragedy: Politics and Ethnic Divisions. The Quarterly Journal of Economics 112:1203-50.

Feng, Y. 2003. Democracy, Governance and Economic Performance: Theory and Evidence, MIT Press. 
Friedman, E., Johnson, S., Kaufmann, D. and P. Zoido-Lobaton, 2004. Dodging the grabbing hand: the determinants of unofficial activity in 69 countries. Journal of Public Economics 76 (2000) 459-493.

Githongo, J. 2006. Inequality, Ethnicity and the Fight against Corruption in Africa: A Kenyan Perspective. Forthcoming in Economic Affairs.

Gylfason, T. 2001. Natural resources, education, and economic development. European Economic Review 45: 847-859.

Gylfason, T. and G. Zoega. 2006. Natural Resources and Economic Growth: The Role of Investment. The World Economy 29: 1091-1115.

Hamilton, K. and M. Clemens. 1998. Genuine Saving Rates in Developing Countries, Worldbank, Washington D.C. available on http://nweb18.worldbank.org/ESSD/envext.nsf/44ByDocName/GreenAccountingAdj ustedNetSavings

Hendry, D.F., S. Johansen and C. Santos. 2004. Selecting a Regression Saturated by Indicators, unpublished paper, Economics Department, University of Oxford.

Heston, A., Summers, R. and B. Aten. 2002. PWT 6.1. Center for International Comparisons at the University of Pennsylvania (CICUP), October 2002.

http://pwt.econ.upenn.edu/

Jaggers, Keith, and Ted Robert Gurr. 1995. Tracking Democracy's Third Wave with the Polity III Data. Journal of Peace Research 32:469-482.

Keefer, P. and D. Stasavage. 2003. The Limits of Delegation: Veto Players, Central Bank Independence and the Credibility of Monetary Policy. American Political Science Review (August).

Lipset, S. M. 1959. Some Social Requisites of Democracy: Economic Development and Political Legitimacy. American Political Science Review 53: 69-105.

Mehlum, Halvor, Karl Moene, and Ragnar Torvik. 2006. Institutions and the Resource Curse. Economic Journal 116:1-20.

Moore, Mick, 1998, 'Death without Taxes: Democracy, State Capacity and Aid Dependence in the Fourth World, in Towards a Democratic Developmental State, eds. Gordon White and Mark Robinson, Oxford, Oxford University Press.

Olson, M. 1993. Dictatorship, Democracy, and Development. American Political Science Review 87: 567-576.

Olsson, O. 2007. Conflict Diamonds. Journal of Development Economics 82: 267286.

Przeworski, A. and F. Limongi. 1993. Political Regimes and Economic Growth. The Journal of Economic Perspectives 7: 51-69. 
Robinson, James A, Ragnar Torvik, and Thierry Verdier. 2006. Political Foundations of the Resource Curse. Journal of Development Economics 79: 447-468.

Ross, M. L. 2001. Does Oil Hinder Democracy? World Politics 53 (April):325-61.

Ross, M. L. 2004. Does Tax lead to Representation? British Journal of Political Science 34: 229-249.

Ross, M. L. 2006. A Closer Look at Oil, Diamonds, and Civil War. Annual Review of Political Science 9: 263-300.

Sachs, Jeffrey D., and Andrew M. Warner. 2005. "Natural Resource Abundance and Economic Growth." In Leading Issues in Economic Development, ed. G. M. Meier and J. E. Rauch. $8^{\text {th }}$ edition. New York: Oxford University Press.

Smith, B. 2004. Oil Wealth and Regime Survival in the Developing World, 19601999, American Journal of Political Science 48 (2): 232-246.

Selden, Z. 2004. Neoconservatives and the American Mainstream. Hoover Institution Policy Review, April 2004.

Söderbom, M., Teal, F., Wambugu, A. and G. Kahyarara, 2006. The Dynamics of Returns to Education in Kenyan and Tanzanian Manufacturing, Oxford Bulletin of Economics and Statistics 68: 261-288.

Tavares, J. and R. Wacziarg, 2001, How Democracy Affects Growth, European Economic Review 45: 1341-1378.

Tilly, Charles, 1975, The Formation of National States in Western Europe, Princeton University Press.

Tornell, Aaron and Philip Lane, 1999. The Voracity Effect, American Economic Review 89: 22-46.

Vicente, P. 2007. Does Oil Corrupt? Evidence from a Natural Experiment in West Africa, Centre for the Study of African Economies.

http://users.ox.ac.uk/ econ0192/oil.pdf

Wooldridge, J. M. 2002. Econometric Analysis of Cross Section and Panel Data. MIT Press: Cambridge MA. 


\section{Appendix}

\section{Descriptive Statistics for the Core Model}

Table A1: Means

\begin{tabular}{l|lllll}
\hline Variable & Obs & Mean & Std. Dev. & Min & Max \\
\hline Growth & 720 & 1.29 & 3.64 & -16.23 & 20.29 \\
ln GDP & 720 & 7.48 & 1.62 & 4.57 & 10.73 \\
Nat. Resources & 720 & 5.99 & 11.84 & 0 & 80.60 \\
Nat. Res. $\mathrm{t}-1$ & 720 & 6.30 & 12.92 & 0 & 106.60 \\
Democracy & 720 & 4.51 & 4.28 & 0 & 10 \\
Checks & 720 & 2.54 & 1.77 & 1 & 17 \\
Ethnic & 718 & 0.46 & 0.26 & 0.012 & 0.93 \\
ln Investment & 686 & 2.57 & 0.62 & 0.60 & 4.03 \\
Gov. Cons. & 713 & 15.66 & 6.81 & 3.67 & 74.32 \\
\hline
\end{tabular}

Table A2: Correlation Coefficients

$\begin{array}{lllllllll} & \text { growth } & \text { In GDP } & \begin{array}{l}\text { Nat. } \\ \text { Res. }\end{array} & \text { Nat.Res. } t-1 & \text { Democr. } & \text { Checks } & \text { Ethnic } & \text { ln Inv. } \\ \text { ln GDP } & 0.115 & 1 & & & & & & \\ \text { Nat. Res. } & -0.101 & -0.068 & 1 & & & & & \\ \text { Nat. Res. } \mathrm{t}-1 & -0.142 & -0.077 & 0.819 & 1 & & & & \\ \text { Democracy } & 0.160 & 0.683 & -0.219 & -0.202 & 1 & & & \\ \text { Checks } & 0.161 & 0.505 & -0.145 & -0.138 & 0.716 & 1 & & \\ \text { Ethnic } & -0.236 & -0.512 & 0.172 & 0.131 & -0.427 & -0.326 & 1 & \\ \text { ln Investment } & 0.278 & 0.687 & -0.029 & -0.056 & 0.448 & 0.358 & -0.469 & 1 \\ \text { Gov. Cons. } & -0.081 & 0.354 & 0.065 & 0.064 & 0.232 & 0.181 & 0.130 & 0.192\end{array}$

Table A3: Checks Scores

\begin{tabular}{lll}
\hline Period & Sample & $\begin{array}{l}\text { High Natural Rents } \\
\text { Countries }\end{array}$ \\
$1975-1998$ & $2.34(1.72)$ & $1.54(1.34)$ \\
1974 & $1.74(1.41)$ & $1.03(0.16)$ \\
1978 & $1.89(1.35)$ & $1.26(0.70)$ \\
1982 & $2.08(1.51)$ & $1.46(1.10)$ \\
1986 & $2.17(1.59)$ & $1.48(1.43)$ \\
1990 & $2.41(1.89)$ & $1.64(1.89)$ \\
1994 & $2.97(1.87)$ & $2.40(2.00)$ \\
1998 & $2.88(1.87)$ & $2.04(1.59)$ \\
\hline
\end{tabular}

Notes: Standard Deviation in parentheses. 


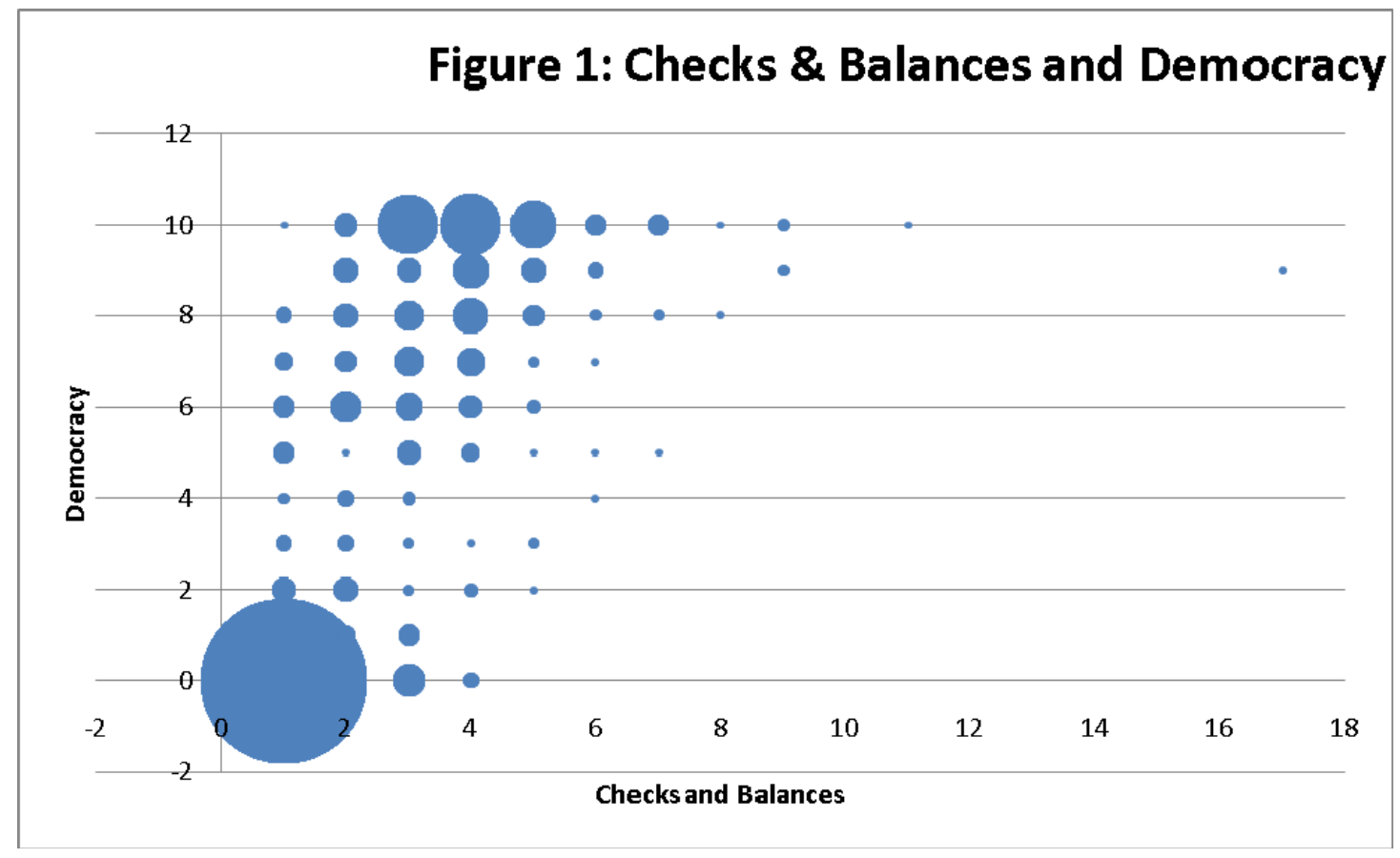

\section{Sample:}

Albania, Algeria, Angola, Argentina, Armenia, Austrialia, Austria, Azerbaijan, Bangladesh, Belarus, Belgium, Benin, Bolivia, Botswana, Brazil, Bulgaria, Burkina Faso, Burundi, Cameroon, Canada, Central African Republic, Chad, Chile, China, Colombia, Dem. Rep. Congo, Rep. Congo, Costa Rica, Cote d'Ivoire, Croatia, Czech Republic, Denmark, Dominican Republic, Ecuador, Egypt, El Salvador, Eritrea, Estonia, Ethiopia, Fiji, Finland, France, Gabon, The Gambia, Georgia, Germany, Ghana, Greece, Guatemala, Guinea, Guinea-Bissau, Haiti, Honduras, Hungary, India, Indonesia, Iran, Ireland, Israel, Italy, Jamaica, Japan, Jordan, Kazakhstan, Kenya, Kuwait, Kirguiz Rep., Laos, Latvia, Lesotho, Macedonia, Madagascar, Malawi, Malaysia, Mali, Mauritania, Mauritius, Mexico, Moldova, Mongolia, Morocco, Mozambique, Namibia, Nepal, Netherlands, New Zealand, Nicaragua, Niger, Nigeria, Norway, Oman, Pakistan, Panama, Papua New Guinea, Paraguay, Peru, Philippines, Poland, Portugal, Romania, Russian Federation, Rwanda, Saudi Arabia, Senegal, Sierra Leone, Singapore, Slovak Republic, Slovenia, South Africa, Sri Lanka, Sudan, Sweden, Syrian Arab Republic, Tanzania, Thailand, Togo, Trinidad and Tobago, Tunisia, Turkey, Turkmenistan, Uganda, Ukraine, United Kingdom, United States, Uruguay, Uzbekistan, Venezuela, Vietnam, Yemen, Zambia, Zimbabwe. 


\section{Data Description and Sources:}

\section{Economic Growth}

We used WDI 2003 data for GDP and population. GDP is measured in constant 1995 US dollars, we divided GDP by the population to calculate per capita GDP. We approximated the growth of per capita GDP by taking the log differences at the beginning and end of each sub period (1970-73, 1974-77, .., 1998-2001) and divided this difference by the number of years, four, and multiplied this by 100 .

\section{GDP per capita}

We measure GDP per capita at the beginning of each sub-period (1970-73, 1974-77, ..., 1998-2001). Data are measured in constant 1995 US dollars and the data source is WDI 2003.

\section{Natural Resource Rents}

Using data from the World Bank's adjusted savings project we calculated the rents for each commodity by subtracting the cost from the commodity price. We then multiplied the rents per unit by the amount extracted and summed across the different commodities. We then calculated the share of rents in GDP. Since the rents are provided in current US dollars we used the WDI 2003 GDP in current dollars to calculate this share. Natural resources for which rent data were available are: oil, gas, coal, lignite, bauxite, copper, iron, lead, nickel, phosphate, tin, zinc, silver and gold. The data are described in Hamilton and Clemens (1998) and available from http://lnweb18.worldbank.org/ESSD/envext.nsf/44ByDocName/GreenAccountingAdj ustedNetSavings

\section{Democracy}

The degree of competition for executive power is measured on a scale of zero (low) to ten (high). We used the Polity IV score at the beginning of each sub-period (1970-73, 1974-77, .., 1998-2001). Source: http://www.cidcm.umd.edu/polity/index.html. The data are described in Jaggers and Gurr (1995).

\section{Investment}

We used total investment as a percentage of GDP and averaged and logged over each sub-period (1970-73, 1974-77, ..., 1998-2001). Data source: PWT as described in Heston, Summers and Aten (2002).

\section{Checks}

This variable captures the number of veto players. This variable is built from several other variables, two of which are the legislative and the executive indices of electoral competitiveness. The checks and balances index ranges from 1 to 17 with higher numbers indicating a higher number of veto players. Data Source: DPI2000, data are described in Beck et al (2001) and Keefer and Stasavage (2003) and are available from http://econ.worldbank.org/view.php?type=18\&id=25467

\section{Ethnic Diversity}

Diversity is a measure of ethnic fractionalization is measured as the probability of two randomly people not belonging to the same ethnic group. This measure of ethnic fragmentation is based on a broad classification of groups, taking into account not 
only language but also other cleavages such as racial characteristics. Data source: Alesina et al (2003).

\section{Regional Dummies}

The regional dummies were obtained from Collier and Dollar (2001).

Sub-Saharan Africa: Angola, Burundi, Benin, Burkina Faso Central African Republic Cote Congo, Rep Cape Verde Djibouti, Eritrea, Ethiopia, Gabon, Ghana, Guinea, The Gambia, Guinea-Bissau, Equatorial Guinea, Kenya, Liberia, Lesotho, Madagascar, Mali, Mozambique, Mauritania, Mauritius, Malawi, Namibia, Niger, Nigeria, Rwanda, Sudan, Senegal, Sierra Leone, Somalia, Sao Tome and Principe, Swaziland, Seychelles, Chad, Togo, Tanzania, Uganda, South Africa, Congo, Dem. Rep., Zambia and Zimbabwe.

South Asia: Afghanistan, Bangladesh, Bhutan, India, Sri Lanka, Maldives, Nepal and Pakistan.

East Asia: China, Indonesia, Japan, Korea, Rep., Malaysia, Philippines, Singapore and Thailand.

Middle East and North Africa: United Arab Emirates, Bahrain, Algeria, Egypt, Arab Rep., Greece, Iran, Islamic Rep., Iraq, Israel, Jordan, Kuwait, Lebanon, Libya, Morocco, Malta, Oman, Portugal, Qatar, Saudi Arabia, Syrian Arab Republic, Tunisia and Yemen, Rep.

Eastern and Central Europe: Albania, Armenia, Azerbaijan, Bulgaria, Bosnia and Herzegovina, Belarus, Czech Republic, Estonia, Georgia, Croatia, Hungary,Kazakhstan, Kyrgyz Republic, Lithuania, Latvia, Moldova, Macedonia, FYR, Poland, Romania, Russian Federation, Slovak Republic, Slovenia, Tajikistan, Turkmenistan, Turkey, Ukraine, Uzbekistan and Yugoslavia (Serbia/Montenegro). 
${ }^{\mathrm{i}}$ During the resource boom of the 1970 s, the average resource-rich country scored only 0.96 on the Polity IV scale of political rights (the scale ranges 0-10). By the mid-1990s the score had risen to 3.47. The scale ranges from 0-10. Details of these figures are given in Section 3.

ii This data set has now been used by a number of studies, for example Ross (2006) analyzes the link between the resource rents from oil and civil war.

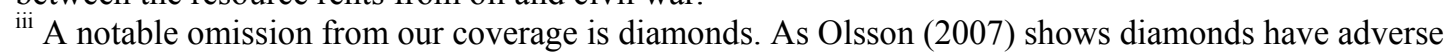
effects on economic growth conditional upon poor institutions, a result entirely consistent with our subsequent results.

${ }^{\text {iv }}$ For two observations this average is larger than 100 . This is possible because the numerator and denominator are based on different measurement concepts, rents and value added. In any case in our regression analysis we could not use these observations because other data were missing.

${ }^{\mathrm{v}}$ We would like to thank David Hendry for this suggestion. Country dummies included are: Armenia, Australia, Azerbaijan, Botswana, Central African Republic, Chile, China, Dominican Republic, Egypt, Estonia, Georgia, Guinea, Haiti, Ireland, Jamaica, Japan, Lesotho, Lithuania, Latvia, Madagascar, Macedonia, Mauritius, Niger, Nicaragua, Norway, Oman, Peru, Philippines, Portugal, Sierra Leone, Tunisia, Uzbekistan, Vietnam, Democratic Republic of the Congo and Zambia.

${ }^{v i}$ Due to the democracy interaction term our model is non-linear in the variables and we use the test for endogeneity as described in Wooldridge (2002). We calculate the residuals from the first stage regression and include them in the second stage regression. A zero coefficient on the residual is interpreted as an indication that endogeneity does not pose major problems and that OLS regression can be used. This approach is sometimes referred to as the 'control function' approach. A recent application can be found in Söderbom et al (2006, section V).

${ }^{\text {vii }}$ Results available upon request. 